\title{
Health Related Lifestyle Behaviors among Students at a Vocational Education Center in Turkey
}

\author{
Melis Naçar ${ }^{1 *}$, Fevziye Çetinkaya1, Zeynep Baykan1, Gökmen Zararsiz², Gülay Yilmazel³, \\ Mehmet Sağiroğlu ${ }^{1}$ \\ ${ }^{1}$ Department of Medical Education, School of Medicine, Erciyes University, Kayseri, Turkey \\ ${ }^{2}$ Department of Biostatistics, School of Medicine, Erciyes University, Kayseri, Turkey \\ ${ }^{3}$ Department of Nursery, School of Health, Hitit University, Çorum, Turkey \\ Email: *mnacar@erciyes.edu.tr
}

Received 5 October 2015; accepted 14 November 2015; published 17 November 2015

Copyright (C) 2015 by authors and Scientific Research Publishing Inc.

This work is licensed under the Creative Commons Attribution International License (CC BY). http://creativecommons.org/licenses/by/4.0/

(c) (i) Dpen Access

\begin{abstract}
Background: This study assessed health promoting lifestyle behaviors (HPLP) among apprentices trained in the Kayseri Turkey Vocational Education Center. Methods: This descriptive study was performed in 2012 in a province of Turkey. The study group included a cohort of 332 students attending the Vocational Education Center. All data were collected by using a 54-item (6-item related with socio-demographic and 48 item related with HPLP Scale) questionnaire. Data were evaluated by independent $t$ test, One-Way Anova and Multiple logistic regression analyses. Results: In the study group, $\mathbf{8 8 . 0} \%$ were male and $\mathbf{1 2 . 0 \%}$ were female. The mean age of participants was $17.1 \pm 1.5$ years. The mean HPLP scale score was $111.2 \pm 22.0$. The mean sub-scale scores were as follows: self-actualization $34.6 \pm 7.5$, interpersonal relations $18.6 \pm 4.3$, exercise $9.4 \pm 3.0$, nutrition $13.9 \pm 3.5$, stress management $16.2 \pm 4.0$, and health responsibility $18.6 \pm 5.7$. Age groups, regular payment and job satisfaction were significant variables for sub-scales of HPLP. In the regression analysis, job satisfaction had a significant impact on HPLP sub-scale scores. Conclusions: Healthy lifestyle behaviors were moderate level among students. Physical activity and health responsibility scores were the lowest scores. "Health Protection and Development" should be included as a standard component of vocational education.
\end{abstract}

\section{Keywords}

Health Promotion, Apprentice, Healthy Life, Education, Scale

\footnotetext{
"Corresponding author.
}

How to cite this paper: Naçar, M., Çetinkaya, F., Baykan, Z., Zararsiz, G., Yilmazel, G. and Sağiroğlu, M. (2015) Health Related Lifestyle Behaviors among Students at a Vocational Education Center in Turkey. Health, 7, 1536-1544. 


\section{Introduction}

The development of health consciousness, or the perception that personal health is an important part of daily life, inevitably enhances protection from disease and injury through the avoidance of risky behaviors [1] [2].

Health enhancement includes not only the prevention of illness, but also the promotion of general health and wellbeing [3] [4]. A healthy lifestyle consists of accepting personal responsibility for one's own health, selffulfillment, health screenings, stress management, healthy diet and regular exercise [5]. Previous studies have suggested that lifestyle choices may account for as much as 50\% of preventable deaths; lifestyle factors during childhood, adolescence, and adulthood are major factors in human disease [6] [7]. Behavior patterns are typically established during adolescence [8]; instruction of children and adolescents in health consciousness is more effective than alteration of adult behavior patterns. The extent to which childhood labor, living conditions, and harmful occupational environments affect the establishment of a healthy lifestyle remains unknown.

Dust, toxic chemical agents, lighting, heating, crowded workplaces, humidity, smell, ionizing radiation and other elements of harmful occupational environments threaten youth health [9]. It is vital that all individuals are knowledgeable regarding disease prevention and management in these environments. Childhood labor may lead to the slowing of normal development and growth, therefore, it is critically important that all underage laborers possess the health related knowledge that may provide protection from disease throughout life.

In Turkey, an apprentice is defined as one who receives knowledge, skills and on-the-job training in accordance with an apprenticeship agreement. An apprentice must be at least 14 years old, a primary school graduate, and healthy enough to meet the responsibilities and requirements of the workplace. An apprentice attends school one day per week and works five days a week.

A limited number of studies have been conducted on the lifestyle choices of working youth in Turkey; therefore, there is an urgent need for studies that can help assist in establishing health consciousness in this population.

This study aims to evaluate lifestyle instruction in working youth and to study the factors that influence these behaviors.

\section{Material and Method}

The research protocol was drafted in accordance with the Helsinki principles and Erciyes University reviewed and approved the study protocol. All participating students provided informed consent documentation. A written administrative permit was obtained from the Kayseri Provincial Directorate for National Education to conduct a survey in the Occupational Education Center.

\subsection{Study Design}

This study was conducted between January and February of 2012 at an Occupational Education Center attended by 3735 students.

\subsection{Sample}

The study recruitment goal was 400 students, or approximately $10 \%$ of the student body. The students were selected at random for participation in the study. Of the 400 students contacted by the researchers, 68 were withdrawn from the study due to refusal to participate or an inability to contact the student. The final study group included 332 students (83\%).

\subsection{Survey}

The data was collected by survey. Participating students completed the survey under the supervision of a researcher. The first section of the survey examined the socio-demographic attributes of the participants (age, gender, education status of their parents, students' jobs, places they have spent the most of their lives) and self-reported economic status, perceptions regarding personal health, pre-existing disease, weight, height, apprenticeship, and workplace environment. The total period of study varies according to training program (two or three years for elementary school graduates; reduced by half for high school graduates). The classrooms are divided by grade. 
The second part of the survey was adapted from Walker, Sechrist and Pender in 1987 [5], with a Turkish validation study conducted by Esin [10] in 1997. This study is referred to as the "Health Promoting Lifestyle Profile (HPLP) Scale”. The coefficient of internal consistency (Cronbach Alpha) was reported as 0.91.

The questionnaire included the following subgroups: self-development, health responsibility, exercise, nutrition, interpersonal support and stress management.

\subsection{Measures}

Responses were scored using a four point Likert-type scale, with "Anytime" = 1 point, "Sometimes" = 2 point, "Often" = 3 points, and "Regularly" = 4 points.

The self-development component (range: 13 - 52), consisting of 13 questions, determines an individual's life goals and self-fulfillment. The health responsibility component (range: 10 - 40), consisting of ten questions, determines the extent to which an individual participates in their own health. The exercise component (range: 5 20 ), consisting of five questions, evaluates the degree to which an individual practices regular exercise. The nutrition component (range: 6 - 24), consisting of six questions, evaluates an individual's food consumption. The interpersonal support component (range: 7 - 28), consisting of seven questions, determines an individuals' level of engagement with family and friends. The stress management component (range: 7 - 28), consisting of seven questions, evaluates an individual's ability to recognize and manage sources of stress. Overall, the HPLP Scale (range: 48 - 192) consists of 48 unique questions.

According to the World Health Organization, a Body Mass Index (BMI) of less than 18.5 is defined as underweight, BMI of 18.5 - 24.9 is defined as normal, BMI of 25.0 - 29.9 is overweight, and BMI of 30.0 and greater is defined as obese [11].

\subsection{Statistical Analysis}

IBM SPSS Statistics 20.0 (IBM Inc., Chicago, IL, USA) was used for all data analysis. The Shapiro-Wilk's Test was used to determine conformation with the normal distribution. Multiple Regression Analysis was conducted to evaluate the influence of variables such as gender, rank, age, pre-existing chronic disease, and employment status on the healthy lifestyle scale score or on sub-scale scores. Age and daily work hours were treated as continuous variables. The threshold of statistical significance was set at $\mathrm{p}<0.05$.

\section{Results}

The average age of the apprentices participating in the study was $17.1 \pm 1.5$ years, with $88.0 \%$ of the study group composed of males and females accounting for $12 \%$ of the study group. A total $39.8 \%$ of the apprentices were in the first year of study. The participants reported that $63.0 \%$ of their fathers and $68.1 \%$ of their mothers were primary school graduates. $71.6 \%$ of the participating apprentices indicated that their fathers are working and $15.4 \%$ retired; $16.6 \%$ indicated that their mothers are working and $4.5 \%$ retired. $59.9 \%$ of study participants had spent the majority of their life living in urban areas.

The socio-demographic characteristics of the students are given in Table 1.

The average age at which the participants started apprenticeships was $15.4 \pm 1.7$ years (range: 10 - 28 years). $41.9 \%$ of the students indicated that their term of employment had been two years or less; $75.3 \%$ of participants indicated that they were paid regularly; $15.4 \%$ of participants were provided with insurance by their employer. $15.6 \%$ of the students were underweight and $71.0 \%$ of students had normal body weight. The mean Body Mass Index (BMI) was $21.7 \pm 3.5$. A total of $7.5 \%$ of participants had been diagnosed with a chronic disease.

Distribution and healthy lifestyle behavior scale scores of students are given in Table 2. The average overall HPLP scale score was $111.2 \pm 22.0$ and the average subgroup scale scores were $34.6 \pm 7.5$ for self-fulfillment, $18.6 \pm 4.3$ for support among individuals, $9.4 \pm 3.0$ for exercise, $13.9 \pm 3.5$ for nutrition, $16.2 \pm 4.0$ for stress management, and $18.6 \pm 5.7$ for health responsibility (Table 2).

Health Promoting Lifestyle Profile Scale and Subscale scores of students according to some characteristics are given in Table 3. There was no difference among male students and female students in terms of the HPLP scores. Class and chronic disease diagnosis were not associated with significant differences in HPLP scores. Gender, rank, age group, pre-existing chronic disease, employment status and job satisfaction were not associated with differences in exercise sub-scale scores. Gender, rank, age group, and pre-existing chronic disease 
were not associated with significant differences in nutrition sub-scale scores, although job satisfaction was associated with higher nutrition sub-scale scores compared to individuals who reported being unsatisfied with their current employment (Table 3).

Table 1. The socio-demographic characteristics of the students.

\begin{tabular}{|c|c|c|}
\hline Characteristics & $\mathrm{n}$ & $\%$ \\
\hline \multicolumn{3}{|l|}{ Gender } \\
\hline Male & 292 & 88.0 \\
\hline Female & 40 & 12.0 \\
\hline \multicolumn{3}{|l|}{ Grade } \\
\hline First year & 132 & 39.8 \\
\hline Last year & 200 & 60.2 \\
\hline \multicolumn{3}{|l|}{ Age Groups } \\
\hline $15-17$ & 213 & 64,2 \\
\hline 18 and $\uparrow$ & 119 & 35.8 \\
\hline \multicolumn{3}{|l|}{ Mothers education } \\
\hline illiterate/literate & 31 & 9.3 \\
\hline Primary or secondary school & 226 & 61.8 \\
\hline At least high school & 75 & 22.6 \\
\hline \multicolumn{3}{|l|}{ Fathers Education } \\
\hline Illiterate/literate & 15 & 4.5 \\
\hline Primary or secondary school & 209 & 63.0 \\
\hline At least high school & 108 & 32.5 \\
\hline \multicolumn{3}{|l|}{ Mothers occupation } \\
\hline Working & 55 & 16.6 \\
\hline Retired & 15 & 4.5 \\
\hline Housewife & 262 & 78.9 \\
\hline \multicolumn{3}{|l|}{ Fathers occupation } \\
\hline Working & 238 & 71.6 \\
\hline Retired & 51 & 15.4 \\
\hline Not working & 43 & 13.0 \\
\hline
\end{tabular}

The place mostly lived in

$\begin{array}{lll}\text { Rural area } & 133 & 40.1 \\ \text { Urban area } & 199 & 59.9\end{array}$

Economic status (according to their evaluation)

Good 137

$137 \quad 41.3$

Moderate 169

50.9

Bad

26

7,8

\begin{tabular}{ccc|}
\hline Presence of chronic disease & & \\
\hline Yes & 25 & 7.5 \\
No & 307 & 92,5 \\
\hline Perception of health situation & & \\
\hline Very good & 72 & 21.7 \\
Good & 156 & 47.0 \\
Moderate/Bad & 104 & 31.3 \\
\hline
\end{tabular}


Table 2. Distribution and healthy lifestyle behavior scale scores of students.

\begin{tabular}{ccccc}
\hline HPLP and subscales & Items & Range of obtainable scores (min-max) & Mean score \pm SD & Items mean score \pm SD $^{*}$ \\
\hline Self-actualization & 13 & $13-52$ & $34.6 \pm 7.5$ & $2.7 \pm 0.6$ \\
Interpersonal relations & 7 & $7-28$ & $18.6 \pm 4.3$ & $2.7 \pm 0.6$ \\
Physical activity & 5 & $5-20$ & $9.4 \pm 3.0$ & $1.9 \pm 0.6$ \\
Nutrition & 6 & $6-24$ & $13.9 \pm 3.5$ & $2.3 \pm 0.6$ \\
Stress management & 7 & $7-28$ & $16.2 \pm 4.0$ & $2.3 \pm 0.6$ \\
Health responsibility & 10 & $10-40$ & $18.6 \pm 5.7$ & $1.9 \pm 0.6$ \\
Total Score & 48 & $48-192$ & $111.2 \pm 22.0$ & $2.3 \pm 0.5$ \\
\hline
\end{tabular}

*The highest possible score in each item four.

Table 3. Health promoting lifestyle profile scale scores of students according to some characteristics.

\begin{tabular}{|c|c|c|c|c|c|c|c|c|}
\hline \multirow{3}{*}{ Variables } & \multirow{3}{*}{$\mathbf{n}$} & \multicolumn{7}{|c|}{ Health Promoting Lifestyle Profile Scale Scores } \\
\hline & & Self-actualization & $\begin{array}{c}\text { Health } \\
\text { responsibility }\end{array}$ & $\begin{array}{c}\text { Physical } \\
\text { activity }\end{array}$ & Nutrition & $\begin{array}{l}\text { Interpersonal } \\
\text { relations }\end{array}$ & $\begin{array}{c}\text { Stress } \\
\text { management }\end{array}$ & Total \\
\hline & & $\mathrm{X} \pm \mathrm{SD}$ & $\mathbf{X} \pm \mathrm{SD}$ & $\mathrm{X} \pm \mathrm{SD}$ & $\mathrm{X} \pm \mathrm{SD}$ & $\mathrm{X} \pm \mathrm{SD}$ & $\mathrm{X} \pm \mathrm{SD}$ & $\mathrm{X} \pm \mathrm{SD}$ \\
\hline \multicolumn{9}{|l|}{ Gender } \\
\hline Male & 292 & $34.6 \pm 7.6$ & $18.6 \pm 5.7$ & $9.5 \pm 3.1$ & $14.0 \pm 3.4$ & $18.7 \pm 4.4$ & $16.3 \pm 4.1$ & $111.6 \pm 22.5$ \\
\hline \multirow[t]{2}{*}{ Female } & 40 & $34.5 \pm 6.7$ & $19.0 \pm 5.3$ & $8.7 \pm 2.5$ & $13.1 \pm 3.5$ & $17.5 \pm 3.1$ & $15.6 \pm 3.7$ & $108.3 \pm 18.0$ \\
\hline & & $\mathrm{p}=0.933$ & $\mathrm{p}=0.712$ & $\mathrm{p}=0.120$ & $\mathrm{p}=0.095$ & $\mathrm{p}=0.087$ & $\mathrm{p}=0.311$ & $\mathrm{p}=0.385$ \\
\hline \multicolumn{9}{|l|}{ Grade } \\
\hline First year & 132 & $34.8 \pm 7.0$ & $18.8 \pm 4.8$ & $9.6 \pm 3.0$ & $14.0 \pm 3.2$ & $18.5 \pm 4.2$ & $16.5 \pm 3.9$ & $112.0 \pm 20.3$ \\
\hline \multirow[t]{2}{*}{ Last year } & 200 & $34.4 \pm 7.9$ & $18.5 \pm 6.2$ & $9.3 \pm 3.0$ & $13.9 \pm 3.6$ & $18.7 \pm 4.4$ & $16.0 \pm 4.1$ & $110.6 \pm 21.2$ \\
\hline & & $p=0.677$ & $p=0.640$ & $p=0.419$ & $\mathrm{p}=0.692$ & $p=0.767$ & $\mathrm{p}=0.254$ & $\mathrm{p}=0.581$ \\
\hline \multicolumn{9}{|l|}{ Age Groups } \\
\hline $15-17$ & 213 & $34.9 \pm 7.2$ & $18.0 \pm 5.7$ & $9.5 \pm 3.0$ & $14.1 \pm 3.4$ & $18.6 \pm 4.2$ & $16.6 \pm 4.0$ & $112.2 \pm 21.2$ \\
\hline \multirow[t]{2}{*}{18 and $\uparrow$} & 119 & $34.1 \pm 8.0$ & $18.2 \pm 5.7$ & $9.2 \pm 3.0$ & $13.6 \pm 3.5$ & $18.6 \pm 4.5$ & $15.6 \pm 4.0$ & $109.3 \pm 23.4$ \\
\hline & & $\mathrm{p}=0.377$ & $\mathrm{p}=0.248$ & $p=0.388$ & $\mathrm{p}=0.154$ & $\mathrm{p}=0.6998$ & $p=0.045$ & $p=0.262$ \\
\hline \multicolumn{9}{|c|}{ Presence of chronic disease } \\
\hline Yes & 25 & $33.1 \pm 8.7$ & $19.1 \pm 6.7$ & $10.1 \pm 3.4$ & $13.3 \pm 4.2$ & $18.2 \pm 4.8$ & $15.8 \pm 4.9$ & $109.6 \pm 28.8$ \\
\hline \multirow[t]{2}{*}{ No } & 307 & $34.7 \pm 7.4$ & $18.6 \pm 5.6$ & $9.3 \pm 3.0$ & $14.0 \pm 3.4$ & $18.6 \pm 4.3$ & $16.3 \pm 4.0$ & $111.3 \pm 21.4$ \\
\hline & & $\mathrm{p}=0.317$ & $p=0.659$ & $\mathrm{p}=0.239$ & $\mathrm{p}=0.359$ & $p=0.601$ & $\mathrm{p}=0.544$ & $p=0.706$ \\
\hline \multicolumn{9}{|c|}{ Regular pick up fees } \\
\hline Yes & 260 & $34.9 \pm 7.5$ & $18.8 \pm 5.7$ & $9.5 \pm 3.1$ & $14.2 \pm 3.4$ & $18.8 \pm 4.2$ & $16.3 \pm 4.0$ & $112.3 \pm 21.8$ \\
\hline \multirow[t]{2}{*}{ No } & 72 & $33.4 \pm 7.4$ & $17.8 \pm 5.4$ & $8.8 \pm 2.9$ & $12.9 \pm 3.5$ & $17.8 \pm 4.4$ & $15.6 \pm 4.1$ & $105.9 \pm 21.8$ \\
\hline & & $p=0.143$ & $p=0.204$ & $p=0.084$ & $p=0.009$ & $p=0.019$ & $\mathrm{p}=0.211$ & $p=0.033$ \\
\hline \multicolumn{9}{|l|}{ Job satisfaction } \\
\hline Satisfied & 270 & $35.6 \pm 7.4$ & $19.0 \pm 5.8$ & $9.5 \pm 3.0$ & $14.2 \pm 3.5$ & $18.9 \pm 4.2$ & $16.4 \pm 4.0$ & $113.4 \pm 21.7$ \\
\hline Undecided & 42 & $30.0 \pm 6.9$ & $17.2 \pm 5.0$ & $9.5 \pm 2.8$ & $13.0 \pm 2.9$ & $17.6 \pm 4.1$ & $15.0 \pm 3.8$ & $101.9 \pm 21.6$ \\
\hline \multirow[t]{2}{*}{ Not satisfied } & 20 & $30.3 \pm 6.0$ & $16.3 \pm 4.3$ & $8.1 \pm 3.0$ & $11.8 \pm 3.0$ & $16.1 \pm 5.1$ & $16.0 \pm 4.4$ & $99.3 \pm 18.1$ \\
\hline & & $p=0.0001$ & $p=0.029$ & $\mathrm{p}=0.157$ & $\mathrm{p}=\mathbf{0 . 0 0 2}$ & $p=0.005$ & $p=0.091$ & $p=0.0001$ \\
\hline
\end{tabular}

Job satisfaction was the most significant independent predictor of self-fulfillment, health responsibility, interpersonal support, stress management and total score; both job satisfaction and daily work status were significant predictors of nutrition sub-scale score. Job satisfaction accounted for $8.4 \%$ of variation in the self-fulfillment sub-scale score, $2.0 \%$ of the variation in health responsibility sub-scale score, $5.4 \%$ of the variation in nutrition 
sub-scale score (along with daily work status), $2.7 \%$ of variation in interpersonal support sub-scale score, $1.2 \%$ of the variation in stress management, sub-scale score, and $4.7 \%$ of the variation in total healthy lifestyle scale score (Table 4).

In an effort to model the relationship between job satisfaction and daily work variables with individual sub-scale scores, a linear regression analysis was performed. The analysis revealed the following relationships:

Self-actualization $=30.049+(5.564 \times$ Job Satisfaction $)$

Health responsibility $=16,933+(2.085 \times$ Job Satisfaction $)$

Nutrition $=14.942+(1.619 \times$ Job Satisfaction $)+(2.085 \times$ Daily work $)$

Interpersonal relations $=17.083+(1.846 \times$ Job Satisfaction $)$

Stress management $=15.306+(1.138 \times$ Job Satisfaction $)$

Total HPLP $=101.069+(12.315 \times$ Job Satisfaction $)$

All of the regression equations produced were found to be statistically significant $(\mathrm{p}<0.05)$. The relationship between the scale score and the job satisfaction was positive (Beta $>0$ ), while the relationship between the scale score and daily work status was negative (Beta $<0$ ). Satisfaction with the current job increased self-fulfillment score by $28.9 \%$, health responsibility score by $14.2 \%$, nutrition scale score by $18.2 \%$, group support score by $16.6 \%$, stress management score by $11.1 \%$, and increased total scale score by $21.6 \%$ (Table 4 ).

\section{Discussion}

The present study evaluated health-related behavior among a population of young workers who are at high risk

Table 4. Evaluation of healthy lifestyles of various variables impact on the scale and subscale scores with multiple linear regression analysis in the study group.

\begin{tabular}{|c|c|c|c|c|c|}
\hline Variable & $b_{i}$ & $S\left(b_{i}\right)$ & BETA & $t$ & $\mathbf{p}$ \\
\hline \multicolumn{6}{|l|}{ Self-actualization } \\
\hline Constant & 30.049 & 0.924 & - & 32.517 & $<0.001$ \\
\hline Job satisfaction & 5.564 & 1.025 & 0.289 & 5.427 & $<0.001$ \\
\hline \multicolumn{6}{|c|}{$s=7.217, R^{2}=0.084(F=29.453, \mathrm{p}<0.001)$} \\
\hline \multicolumn{6}{|l|}{ Health responsibility } \\
\hline Constant & 16.933 & 0.724 & - & 23.390 & $<0.001$ \\
\hline Job satisfaction & 2.085 & 0.800 & 0.142 & 2.605 & 0.010 \\
\hline \multicolumn{6}{|c|}{$s=5.608, R^{2}=0.020,(F=6.788, \mathrm{p}=0.010)$} \\
\hline \multicolumn{6}{|l|}{ Nutrition } \\
\hline Constant & 14.942 & 1.081 & - & 13.825 & $<0.001$ \\
\hline Job satisfaction & 1.619 & 0.491 & 0.182 & 3.297 & 0.001 \\
\hline Daily work & -0.217 & 0.090 & -0.134 & -2.415 & 0.016 \\
\hline \multicolumn{6}{|c|}{$s=3.347, R^{2}=0.054,(F=8.793, \mathrm{p}<0.001)$} \\
\hline \multicolumn{6}{|l|}{ Interpersonal relations } \\
\hline Constant & 17.083 & 0.549 & - & 31.094 & $<0.001$ \\
\hline Job satisfaction & 1.846 & 0.607 & 0.166 & 3.040 & 0.003 \\
\hline \multicolumn{6}{|c|}{$s=7.217, R^{2}=0.027,(F=9.240, \mathrm{p}=0.003)$} \\
\hline \multicolumn{6}{|l|}{ Stress management } \\
\hline Constant & 15.306 & 0.508 & - & 30.104 & $<0.001$ \\
\hline Job satisfaction & 1.138 & 0.564 & 0.111 & 2.016 & 0.045 \\
\hline \multicolumn{6}{|c|}{$s=4.004, R^{2}=0.012,(F=4.065, \mathrm{p}=0.045)$} \\
\hline \multicolumn{6}{|l|}{ Total } \\
\hline Constant & 101.069 & 2.825 & - & 35.779 & $<\mathbf{0 . 0 0 1}$ \\
\hline Job satisfaction & 12.315 & 3.121 & 0.216 & 3.946 & $<0.001$ \\
\hline \multicolumn{6}{|c|}{$s=21.513, R^{2}=0.047,(F=15.572, \mathrm{p}<0.001)$} \\
\hline
\end{tabular}


of developing chronic disease. Students at the Apprenticeship Education Center scored $111.2 \pm 22.0$ out of 192 possible points on the HPLP scale; expressed as a four-point scale, this corresponds to $2.3 \pm 0.5$ (Table 2).

Our results were lower than results reported in a previous study [12] (117.43 \pm 19.5$)$ of adolescent workers and lower $(118.5 \pm 21.4)$ than the average for Higher Education Occupational Schools in Kayseri. The health responsibility $(1.9 \pm 0.6)$ and exercise $(1.9 \pm 0.6)$ sub-scores were the lowest scoring categories in the present study (Table 2).

In a previous study of Turkish high school students [13], the health responsibility (1.9 \pm 0.5$)$ and exercise (2.2 \pm 0.7 ) sub-scores were also the lowest scoring categories. These results are similar to the results of other studies that have applied the HPLP scale [14] [15].

Apprentices in the present study reported the highest scores for group support (2.7 \pm 0.6$)$ and self-fulfillment sub-groups $(2.7 \pm 0.6)$ (Table 2$)$. This result was similar to previous reports, both internationally and domestically, using the same scale in comparable populations [13] [16]-[18]. Gender, grade, age, and existence of a chronic disease were not associated with meaningful differences in HPLP scale scores. However, regular pay and job satisfaction were associated with higher HPLP scores. Regression analysis revealed that job satisfaction was a significant factor in total HPLP Scale and the sub-scale points, however other variables were not found to be meaningful (Table 3, Table 4). There was no difference in HPLP score or sub-scores between freshman students and those who were enrolled in advanced classes. The inclusion of health and behavioral instruction in apprenticeship training is important for the improvement of health outcomes in this population. There was no age-dependent difference in total HPLP score, self-fulfillment, health responsibility, exercise, nutrition, interpersonal support subs-scores. This is consistent with the published literature [17]. Age was not a significant factor in the multiple regression analysis. Total HPLP score and sub-scale scores increased with age, similar to previous studies [12] [19]. However, the stress management sub-scale score for students' age 15 - 17 was significantly higher relative to students aged 18 and over. Thus, while overall healthy behavior does not increase with age, stress management ability generally decreases. Job satisfaction affects the organizational behavior of employees. The characteristics of a job influence job satisfaction, motivation and self-fulfillment behavior [20] [21]. The self-fulfillment sub-scores were much higher among individuals who reported high levels of job satisfaction. In the present study, the healthy responsibility sub-scores were significantly higher among participants who reported being satisfied with their current jobs. Self-responsibility that develops during childhood and adolescence persists during adulthood.

In this study, male apprentices attending the first grade, who were diagnosed with a chronic disease, who got paid regularly, and who reported being pleased with their jobs scored higher in the exercise sub-scale. Exercise scores decreased with increasing age $(\mathrm{p}<0.05)$. Previous studies conducted in Turkey support these findings [12] [22] [23]. Physical activity decreases over time, particularly among adolescents [24]. Regular exercise during childhood and adolescence has a positive influence on long-term health. Regular exercise is associated with reduced risk of coronary artery disease, improved blood pressure, enhanced immunity, reduced risk of osteoporosis, and longevity [1]. Hence, regular exercise is vital for apprentices and other adolescent populations. Healthy growth and development requires adequate and balanced nutrition. General nutritional requirements increase during adolescence. The additional expenditure of calories in the workplace further increases nutritional requirements. Nutritional inadequacies inevitably slow development and decrease workplace productivity [25]. Gender, rank, age group, and pre-existing chronic disease did not significantly influence the nutrition sub-scale score. In our study, nutrition sub-scale scores were higher among participants who reported regular pay and satisfaction with their job.

Group support plays a key role in comfortable assimilation to new work conditions [26]. Communicating with others is a part of a healthy lifestyle. Group support has a positive effect on physical health and the absence of group support may contribute to depression and other diseases [27]. In the present study, group support sub-scores were higher among individuals who reported good job satisfaction. In a previous study conducted in China, poor social support was shown to be associated with dissatisfaction [28]. Job satisfaction is a significant variable affecting quality of life [29]. In a study evaluating the relationship between job satisfaction and quality of life among factory employees in Japan, employees with higher job satisfaction also reported a higher quality of life [30]. Other studies have supported the conclusion that job satisfaction leads to better quality of life [29] [31]. A number of studies performed around the world and in Turkey support these findings [12] [16] [19] [28].

Negative conditions at a work place have a negative impact on the health of employees [32]. In a study conducted with a similar population attending the Zonguldak Occupational Education Center located in northern 
Turkey [33], 17.1\% of apprentices stated that an inadequate work environment affected their psychological health in a negative way. A stress-free life is an unrealistic goal; however, the weight of stress due to low socioeconomic conditions and harsh conditions is obvious. Therefore, the need for stress management instruction is clear, especially in apprentices age 18 and older. In a study of high school students [13], education in stress management improved stress management knowledge. The development of methods to cope with stress effectively is essential for the minimization of the negative effects of work on the psychological health in young adults.

\section{Conclusion}

In conclusion, HPLP scale evaluation revealed moderate health behavioral awareness among adolescent apprentices, with health responsibility and exercise identified as specific areas in need of improvement. Future studies should promote increased exercise and educate individuals regarding health responsibility. Job satisfaction was the most significant variable influencing HPLP scale scores. Therefore, training in healthy lifestyle practices should be included in all occupational education programs.

\section{References}

[1] Kivelä, K., Elo, S., Kyngäs, H. and Kääriäinen, M. (2014) The Effects of Health Coaching on Adult Patients with Chronic Diseases: A Systematic Review. Patient Education \& Counseling, 97, 147-157. http://dx.doi.org/10.1016/j.pec.2014.07.026

[2] Sauter, S.L. (2013) Integrative Approaches to Safeguarding the Health and Safety of Workers. Industrial Health, 51, 559-561. http://dx.doi.org/10.2486/indhealth.MS5106ED

[3] Paredes-López, O., Cervantes-Ceja, M.L., Vigna-Pérez, M. and Hernández-Pérez, T. (2010) Berries: Improving Human Health and Healthy Aging, and Promoting Quality Life-A Review. Plant Foods for Human Nutrition, 65, 299-308. http://dx.doi.org/10.1007/s11130-010-0177-1

[4] Buranatrevedh, S. and Sweatsriskul, P. (2005) Model Development for Health Promotion and Control of Agricultural Occupational Health Hazards and Accidents in Pathumthani, Thailand. Industrial Health, 43, 669-676. http://dx.doi.org/10.2486/indhealth.43.669

[5] Walker, S.N., Sechrist, K.R. and Pender, N.J. (1987) The Health-Promoting Lifestyle Profile: Development and Psychometric Characteristics. Nursing Research, 36, 76-81. http://dx.doi.org/10.1097/00006199-198703000-00002

[6] Fish, C. and Nies, M.A. (1996) Health Promotion Needs of Students in a College Environment. Public Health Nursing, 13, 104-111. http://dx.doi.org/10.1111/j.1525-1446.1996.tb00227.x

[7] Spear, H.J. and Kulbok, P.A. (2001) Adolescent Health Behaviors and Related Factors: A Review. Public Health Nursing, 18, 82-93. http://dx.doi.org/10.1046/j.1525-1446.2001.00082.x

[8] Velsor, F.B. (2001) Adolescent School Health. Journal of Pediatric Nursing, 16, 194-196. http://dx.doi.org/10.1053/jpdn.2001.24877

[9] Ferguson, K.T., Cassells, R.C., MacAllister, J.W. and Evans, G.W. (2013) The Physical Environment and Child Development: An International Review. International Journal of Psychology, 48, 437-468. http://dx.doi.org/10.1080/00207594.2013.804190

[10] Esin, M.N. (1999) Sağlıklı yaşam biçimi davranışları ölçeğinin Türkçeye uyarlanması. Hemşirelik Bülten, 2, 87-96.

[11] Centers for Disease Control and Prevention (CDC) (2014) About Body Mass Index for Adults. http://www.cdc.gov/healthyweight/assessing/bmi/adult_bmi/index.html

[12] Ünalan, D., Şenol, V., Öztürk, A., et al. (2007) A Research on the Relation between the Healthy Life Style Behaviors and Self-Care Levels of the Students in Health and Social Programs of Vocational Collages. Journal of Turgut Özal Medical Center, 14, 101-109.

[13] Geckil, E. and Yildız, S. (2006) Adolescent Health Behaviors and Problems. Journal of Hacettepe University School of Nursing, 25, 26-34.

[14] Nacar, M., Baykan, Z., Cetinkaya, F., et al. (2014) Health Promoting Lifestyle Behaviours in Medical Students: A Multicentre Study from Turkey. Asian Pacific Journal of Cancer Prevention, 15, 8969-8974. http://dx.doi.org/10.7314/APJCP.2014.15.20.8969

[15] Felton, G.M., Parsons, M.A., Misener, T.R. and Oldaker, S. (1997) Health Promoting Behaviors of Black and White Collage Women. Western Journal of Nursing Research, 19, 654-666. http://dx.doi.org/10.1177/019394599701900506

[16] Can, H.O., Ceber, E., Sogukpinar, N., Saydam, B.K., Otles, S. and Ozenturk, G. (2008) Eating Habits, Knowledge about Cancer Prevention and the HPLP Scale in Turkish Adolescents. Asian Pacific Journal of Cancer Prevention, 9, 
569-574.

[17] Ulla Díez, S.M. and Pérez-Fortis, A. (2010) Socio-Demographic Predictors of Health Behaviors in Mexican College Students. Health Promotion International, 25, 85-93. http://dx.doi.org/10.1093/heapro/dap047

[18] Hendricks, C.S., Murdaugh, C., Tavakoli, A. and Hendricks, D.L. (2000) Health Promoting Behaviors among Rural Southern Early Adolescents. ABNF Journal, 11, 123-128.

[19] Al-Kandari, F., Vidal, V.L. and Thomas, D. (2008) Health Promoting Lifestyle and Body Mass Index among College of Nursing Students in Kuwait: A Correlational Study. Nursing \& Health Sciences, 10, 43-50. http://dx.doi.org/10.1111/j.1442-2018.2007.00370.x

[20] Chen, L.H. (2008) Job Satisfaction among Information System (IS) Personnel. Computers in Human Behavior, 24, 105-118. http://dx.doi.org/10.1016/j.chb.2007.01.012

[21] Tatsuse, T. and Sekine, M. (2013) Job Dissatisfaction as a Contributor to Stress-Related Mental Health Problems among Japanese Civil Servants. Industrial Health, 51, 307-318. http://dx.doi.org/10.2486/indhealth.2012-0058

[22] Yılmazel, G., Çetinkaya, F. and Nacar, M. (2013) Hemşirelik öğrencilerinde sağlı̆̆ geliştirme davranışları. TAF Preventive Medicine Bulletin, 12, 261-270.

[23] Yılmaz, U. and Bayat, M. (2005) Oto tamirhanelerinde çalışan çocuk işçilerin sağlıklarını koruyucu davranışları ile iş ortamı ve çalışma koşullarının değerlendirilmesi. Journal of Health Science, 14, 37-44.

[24] Dumith, S.C., Gigante, D.P., Domingues, M.R. and Kohl, H.W. (2011) Physical Activity Change during Adolescence: A Systematic Review and a Pooled Analysis. International Journal of Epidemiology, 40, 685-698. http://dx.doi.org/10.1093/ije/dyq272

[25] Ceylan, S.S. and Metin, Ö. (2009) Working Condition Children Who Work in Industry and Educated at Apprenticeship Education Center. Firat Sağllk Hizmetleri Dergisi, 4, 87-101.

[26] Gunnarsdottir, S. and Björnsdottir, K. (2003) Health Promotion in the Workplace: The Perspective of Unskilled Workers in a Hospital Setting. Scandinavian Journal of Caring Sciences, 17, 66-73. http://dx.doi.org/10.1046/j.1471-6712.2003.00122.x

[27] Jocelyn, O.T.M. and Shaunqula, A.W. (2006) Religious Orientation and Social Support on Health Promoting Behaviors of African American College Students. Journal of Community Psychology, 34, 105-115. http://dx.doi.org/10.1002/jcop.20086

[28] Gu, G.Z., Yu, S.F. and Zhou, W.H. (2011) Relationship between Job Satisfaction and Occupational Stress in the Workers of a Thermal Power Plant. Chinese Journal of Industrial Hygiene and Occupational Diseases, 29, 893-897.

[29] Erbay Dündar, P., Bilge, B., Baydur, H., et al. (2006) Quality of Life and Some Related Factors among Young Students of Apprentice School in Manisa. TAF Preventive Medicine Bulletin, 25, 24-29.

[30] Maruyama, S., Sata, H. and Morimoto, K. (1991) Relationship between Working-Life Satisfaction, Health Practices and Primary Symptom/Problem. Nippon Eiseigaku Zassi, 45, 1082-1094. http://dx.doi.org/10.1265/jjh.45.1082

[31] Lerner, D.J., Levine, S., Malspeis, S. and D’Agostino, R.B. (1994) Job Strain and Health-Related Quality of Life in a National Sample. American Journal of Public Health, 84, 1580-1585. http://dx.doi.org/10.2105/AJPH.84.10.1580

[32] Kawakami, N. and Haratani, T. (1999) Epidemiology of Job Stress and Health in Japan: Review of Current Evidence and Future Direction. Industrial Health, 37, 174-186. http://dx.doi.org/10.2486/indhealth.37.174

[33] Sala Razı, G., Kuzu, A., Yıldız, A.N., Ocakcı, A.F. and Çamkuşu Arifoğlu, B. (2009) Self Esteem Communication Skills and Cooping with Stress of Young Workers. TAF Preventive Medicine Bulletin, 8, 17-26. 